\title{
Reflection of Gander Biasness in Shashi Deshpande’s ‘The Dark Holds No Terrors'
}

\author{
Aasif Rashid Wani and Muskan Solanki \\ Ph.D. Research Scholar, Department of English, SUBIS, Barla-Raisen (M.P.) \\ wani.asif119@gmail.com
}

\begin{abstract}
"The treatment of a person or particular group of people differently, in a way that is worse than the way people are usually treated:" 1 Literature is a true expression of life through the medium of language. Its success lies in amalgamation of both ability and morality in such a striking way that art, in the long run, becomes the thought. The Indian English Women Novelists enhanced Indian English fiction through female awareness. Shashi Deshpande is one of the renowned women novelists whose novels bring into light a realistic and influensive demonstration of Indian women's status in the broader societal context. The Dark Holds No Terror explores the trauma of a middleclass working women who has become a trap in the male dominated society. Women were treated as second class citizens were assigned their due place in the novel The Dark Holds No Terrors. In modern Indian fiction the credit of representing the "silent voice" of woman goes to Shashi Deshpande. She unfolds the true picture of educated women, her condition in the society.

Deshpande's novel, The Dark Holds No Terrors, brings out the efforts of a female in a family where a male child is preferred to a female child. The novel reveals how the insensitive attitude of the family towards a female can drive her into a psychiatric state of mind. The central character of the novel is Saru who experiences the lack of interest of her mother and feels guilty herself because, the guilt of mothers' death, her own marriage and her thinking about her husband. He is drowned at the age of seven. Her mother preferred her brother and she is always neglected. Simone de Beauvoir once said, "One is not born, but rather becomes, a woman. It is civilization as a whole that produces this creature which is described as feminine". The present paper is aimed to discuss the Feministic Perspective in Shashi Deshpande's The Dark Holds No Terrors.
\end{abstract}

Key Words: Gander inequality, Feminism, Identity, Voice and Society.

"In childhood a woman should be under her father's control, in youth under her husband's and when her husband is dead, under her sons, she should not have independence" (Adele King) 2

Gander inequality took many forms of injustice in male dominated and traditional ridden Indian communities. Females are trapped from many centuries in old conventional beliefs and tradition of practicing superstitious which demonstrated the indecisive intensification of women independence of free thoughts. In the novels' The Dark Holds No Terrors' the leading character of the novel commenced a search for individual identity. Through identity one can get self-esteem, so search of identity leads her self-realization. This quest of self consciousness is considered the urge, action to be free and attitude of the character. She wants to be free and recognized herself leads her internal liberty which facilitated the central character to acknowledge their roles, with a new beginning, uncrushed by challenges and aggression. 
"we pledge ourselves to liberate all our people from counting bondage of poverty, depression, sufferings, gender and other discrimination" 3 Gender prejudice has been deserted by most authors whose tales teem with affectionate and give up mothers irrespective of the child's sex. This gender compassion can be pragmatic in all the works of Shashi Deshpande, particularly in The Dark Holds No Terrors. The quest for identity is simply conspicuous in the livelihood of Saru, the leading character. Shashi Deshpande's analysis of the dilemma of Sarita through the eyes of humanistic feminism is proof in the novel.

The most important idea of The Dark Holds No Terrors is women's quest for uniqueness, selfexploration and resists to liberated themselves from the boundaries imposed by society; she wants to remain free from all the boundaries of society. The novel witnessed on the predicaments of female characters and their consciousness.

The Dark Hold No Terrors Sarita is meek and diffident, but her confidence is not so strong., belongs to middle family want to vanish the norms of the society, and wants to adopt a new environment in her life which her own mother never believed oh her. Her parental home gave her more pain and sufferings. In her home her parents did not gave her status and position. If a family did not support a female child how they expect from others as well as their own society, her mother hates her She endure in a male-dominated world which is not so easy for a women. She neither submits to nor escapes from the problems but she accepts the hard facts of life and challenged very well. Her own Father gave her second position in her home; he always used to take Dhruva outside for ridding but not her daughter. "Daughters are their mother's business" (DHNT, 105). 4 During her childhood Sarita was burden on her family, after marriage her husband did the same with her and uses her only for sex during night. The wife is not only for sex and domestic works; every husband must give respects to their wives and give them social status. It is a very serotype thinking that the birth of a girl is considered as an ill omen, daughters are the blessing of God from heaven for parents. In the novel the own mother did not accept of her own daughter and thought she came with heavy. Birth day was not precious for Saru . It was always a fascinating though-'I was born'. But of my birth, my mother had said to me once. . "It rained heavily the day you were born. It was terrible." And somehow, it seemed to me that it was my birth that was terrible for her, not the rain (DHNT, 169). 5 The sign of rain is very auspicious. People believed that rain is the sign of new hope, new life as well as new future, but her mother denied this mythical fact.

Her mother's loathing to Sarita and penchant for her brother, Dhruva is undoubtedly expressed from her actions. This developed a fissure between the mother and daughter relationship which prompts to Sarita to chose on the corridor of insurgence. This inequity is so deeply rooted in the brain of Sarita and all her upcoming events get ultimately stained. Her mother managed everything for her brother's birthday. His birthday never celebrated without Puja and other rituals, which clearly shows the birthday of her daughter gives her a kind of annoyance.

"Sometimes, I feel discriminated against, but it does not make me angry. It merely astonishes me. How can any deny themselves the pleasure of my company? It's beyond me" 6

The depiction of Saru's mothers love for her son and hatred for her daughter, give the impression of weak point in the plot. The attachment of mother towards male child exhibits male is more important than female. Her brother has right to give Agni after the death of his parents. "The soul of dead parents would otherwise wander in ferment. (DHNT, 20) 7

Deshpande prolifically discards the stereotyped representation of mother and rejects the use any bathetic sentimental language to illustrate the mother- child relationship. Saru have always denied by 
her parents because of her brother. He got a lopsided love from her parents. Mother always looks at them on different eyes. Unfortunately from her home saru get this gift of indiscrimination.

Don't go out in the sun. You'll get even darker. Who cares? We have to care if you don't. We have to get you married. I don't want to get married. Will you live with us all your life? Why not? You can't And Dhruva? He's different. He's a boy. (The Dark hold no Terrors p.45) 8

This disparity in her mother's behavior of her son and daughter infuriate Saru. Being a conventional Hindu woman, the mother think about, it her obligation to be reminiscent her daughter that she is grown up child and she must act accordingly. It is a mother's accountability to notice that the children particularly the daughters behave well. When Saru reached menarche her familiarity about menstruation is horrendous and sore. Instead of amplification the procedure to her and putting her at ease, the mother scared her with the truth that she would lose blood for years. She is not allowed to enter the kitchen and Puja-room. You have to sleep alone, you have to use separate plate for eating, glass for drinking water, clothes for those days. This creates much tension and confusion in the mind of Saru why it is so and why women are unholy during these days. She felt a burden child, who is very perplexed at every point.

\section{Concluding Remark}

Through the novels Shashi Deshpande, we came to know about the problem of female characters from birth to death, they tried their best to create their own world and develop a concept of new women. They are trapped in conventional norms of society. They have no status in society, in the novel The Dark Hold No Terrors Saru was very inferior person in her own family. She did a crime when she born as women. Instead of encouraging her, Saru mother discouraged her always. During her maturation period her mother treated her like "others". It was not her fault and she did not take herself a menstruation period, it is by nature and no one can deny it. Her mother treated her badly. Every where she was discriminated and ignored child, which leads her rebellious nature. Thus a woman is not only for sexual intercourse and like a servant in home. They too have heart in their body and it is the responsibility of every one to give equal prestige. The rebellious nature of Saru only shows she needs love, respect and care from her family as well as husband, but not mediocre, subordinate position in life.

\section{REFERENCES}

[1] https://dictionary.cambridge.org/dictionary/english/discrimination.

[2] Jacob Neusner, Women and Families, Oregon, the Pilgrim Press, 1999, P 85

[3] https://www.brainyquote.com/topics/gender

[4] Shashi Despande, The Dark Holds No Terrors, New Delhi, Penguin Book, 1990. P 105

[5] Ibid. P 169

[6] https://www.goodreads.com/quotes/tag/discrimination

[7] Ibid. P 20

[8] Ibid. P 45 